\title{
Strategy-based Listening and Pragmatic Comprehension
}

Cristiane Ruzicki CORSETTI

\begin{abstract}
This article addresses the role of strategy-based listening as an alternative methodological approach to develop pragmatic comprehension in L2 contexts. Pragmatic comprehension refers to the understanding of speech acts and conversational implicatures. Listening comprehension comprises both bottom-up and top-down processes. Strategy-based listening encompasses the activation of pragmatic knowledge through pre-listening activities and the development of specific listening micro-skills.An empirical project which included a classroom project carried out with a group of eight learners preparing for the IELTS examination in 2009 corroborated the following assumptions: in order to achieve listening proficiency, learners need practice in making inferences as semantic and pragmatic inferences are embedded in verbal communication; semantic and pragmatic aspects affecting the meaning of utterances can be highlighted via comprehension activities focusing on specific listening subskills. The results of the classroom project suggested that strategy-based listening is potentially capable of directly enhancing pragmatic comprehension but were inconclusive with regards to pragmatic production.
\end{abstract}

Keywords: pragmatic comprehension, bottom-up aspects, top-down aspects, strategy-based listening, second language learners.

\section{Introduction}

This article aims at highlighting therole of strategy based-listening in the development of pragmatic comprehension. It is based on two assumptions: listening extracts are a source of comprehensible input portraying real-life communication and comprehension precedes production. I initially comment on the status of the listening skill across different EFL methods and approaches. I thenaddress pragmatic comprehension and its importance in L2 contexts. Next, I present bottom-up and top-down processes involved in listening comprehension as well as Mendelsohn's framework $(1995,1998)$ for the teaching of strategy-based listening. Finally, I report on the findings of an empirical project carried out with a group of eight Brazilian learners preparing for the IELTS examination in the first semester of 2009.

\section{The status of the listening skill}

A large number of Brazilian learners of Englishplace oral skills as their main learning objective. However, depending on the methodological principles adopted by language institutions, the speaking skill is likely to be prioritised. Nunan(2002) compares listening to the "Cinderella skill" in second language learning as it is too often overlooked by its elder sister, the 
speaking skill. To his mind, most people believe that being proficient in a second language consists of being able to speak and write well. Therefore, receptive skills tend to be considered secondary skills, bearing the status of means to other ends, rather than ends in themselves.

From a historical perspective, the status of the listening skill has varied across time depending on the methodological approach in vogue. According to Nunan (2002), listening every so often becomes popular. In the early grammar translation method, for instance, the reading skill was the focus as translation and grammar studies were the main teaching and learning activities. Nevertheless, with the shift of focus to oral language skills via the audiolingual method, listening became fashionable in the early 1960s. This method was partially based on behaviourism ${ }^{1}$ and used dialogues and drills. Rost (1990) adds that as the audiolingual methodemphasised learner identification of language products, the role of listening was merely to reinforce the recognition of those products in the syllabus.

Listening gained prominence again in the 1980s with Krashen's notion of comprehensible input(1985).Its importance was further reinforced by James Asher's Total Physical Response, a fringe method deriving from Krashen's theory and based on the belief that students learn more effectively if the pressure for production is taken off them at early stages. Similarly, first language acquisition theorists such as Brown (1990) also helped to strengthen the role of the listening skill by demonstrating the importance of developing oracy (i.e. the ability to listen and speak) as well as literacy in school.

Nunan (2002) believes that listening is assuming greater and greater importance in the second language classroom. In his opinion, second language acquisition has given listening a major boost by emphasising the importance of comprehensible input and the assumption that listening is fundamental to speaking since it provides input for the learner. Furthermore, listening extracts can be used for language work as learners are able to notice linguistic items (grammar, functions and vocabulary) in a context. Swain (1985) indicates that learners need to process meaning before they internalise form. Likewise, task-based learning activities may also be centred on reading or listening texts.

Task-based learning is a holistic approach where meaning is central as opposed to the traditional PPP (presentation, practice and production) approach, which focuses mainly on language items. When learners carry out a task, the main focus is on exchanging and understanding meanings rather than on the practice of pre-specified forms or patterns. Learners receive feedback from their teacher on task achievement rather than on language performance. Willis's framework for task-based learning (1996) shows that the tasks learners engage in may be based on reading or listening texts. At a later stage (language focus), learners carry out

\footnotetext{
${ }^{1}$ Behaviourism refers to "a theory of psychology which states that human and animal behaviour can and should be studied in terms of physical processes only" (Richards, J.; Platt, J.; Webber, H., 1985: 27).
} 
consciousness-raising activities ${ }^{2}$ in order to identify and process specific language features present in the previous task text and/or transcript. Therefore, in task-based learning, listening activities also play a role in both task and language focus stages.

Celce-Murcia and Olshtain (2000:102) highlight that "listening is the most frequently used language skill in everyday life". Research indicates that, on average, we use the listening skill twice as much as we speak, four times as much as we read and five times as much as we write. Therefore, bearing learners' communicative aims in mind, listening is a vital component in the language classroom, regardless of the methodological approach adopted by institutions.

\section{Pragmatic comprehension}

A pragmatic view on listening comprehension focuses on what an utterance means to a person in a particular speech situation. In other words, while the semantic structure of a sentence specifies what a sentence means as a structure in a given language, in abstraction from speaker and addressee, "pragmatics deals with that meaning as it is interpreted interactionally in a given situation" (Leech, 1977:1). In other words, pragmatic comprehension refers to the comprehension of pragmatic meaning via spoken discourse(Garcia, 2004). In Thomas's model (1995), pragmatic comprehension involves the comprehension of speech acts (Austin, 1962, Searle, 1969, 1979) and conversational implicatures (Grice, 1975).

Speech Act Theory is grounded on the principle that when people want to express themselves, they produce utterances and, at the same time, perform acts via these utterances. Austin (1962) proposed a three-fold distinction among related acts which take place every time an utterance is produced:locutionary act (the basic act of saying something); illocutionary act (utterances which carry a certain conventional force such as a "promise" and a "warning")and perlocutionaryact (the effect speakers produce upon the feelings and actions of their interlocutors).

Searle (1979) developed Speech Act Theory further by proposing a taxonomy of illocutionary acts into five mutually exclusive and jointly exhaustive classes:

1. Representative or Assertive: statements which commit the speaker to the truth of the assumption expressed; for example, "asserting": "It's raining."

2. Directive: speech acts that speakers use to get someone else to do something; for example, "commanding": "Close the door."

\footnotetext{
${ }^{2}$ Consciousness-raising activities are opposed to practice activities and have the following features (Ellis, 2002: 168):

1.There is an attempt to isolate a specific linguistic feature for focused attention;

2. Learners are provided with data which illustrate the targeted feature;

3. Learners are expected to utilise intellectual effort to understand the targeted feature;

4. Misunderstanding of the grammatical structure by learners leads to clarification in the form of further data and description or explanation;

5. Learners may be required to articulate the rule describing the grammatical structure.
} 
3. Commissive: speech acts which commit the speaker to the performance of a future action; for example, "promising": "I'll finish the paper by tomorrow."

4. Expressive: speech acts which convey the speaker's emotional attitude to the assumption expressed; for instance: "I' $m$ so happy to be here."

5. Declarative: statements which bring about the state of affairs described in the assumption expressed; for example: "I now pronounce you husband and wife."

As for conversational implicatures, Grice (1975) draws a sharp distinction between what someone says and what someone implicates when producing an utterance. "Conventional implicatures" relate to what a speaker literally says and are determined by the conventional meaning of the sentence uttered and also contextual processes of disambiguation and reference fixing. "Conversational implicatures", on the other hand, refer to what a speaker implicates (beyond what is said) and are associated with the existence of some rational principles and maxims which govern conversation.

Grice (1975) claims that people flout conversational maxims in the normal course of a conversation and, above all, this flouting of maxims indicates that a speaker is trying to say something else beyond the conventional meaning of the sentence uttered. In order to convey the implicit meaning of an utterance, speakers rely on a deeper level of co-operation which goes beyond surface meaning. Conversational implicatures are then inferences which arise to preserve the assumption of co-operation.

Returning to the notion of pragmatic comprehension, Garcia (2004) suggests that second language students need to be able to comprehend meaning pragmatically in order tounderstand speakers' intentions; interpret speakers' feelings and attitudes; differentiate speech act meaning such as the difference between a directiveand a commissive; evaluate the intensity of speakers' meaning, such as the difference between a suggestion and a warning;recognise sarcasm, joking, and other facetious behaviour ( conversational implicatures); be able to respond appropriately.

\section{Strategy-based listening}

Listening comprehension, discourse analysis and pragmatics are closely linked. According to Celce-Murcia and Olshtain (2000), when we listen to a communicative message via a lecture or a news broadcast or engage in a conversation, we are listening to a stretch of discourse. The authors state that both L1 and L2 models of the listening processes acknowledge that listening has both bottom-up and top-down aspects. The bottom-up level of the listening process involves prior knowledge of the language system in terms of phonology, grammar and vocabulary. Nunan (2002: 239) states that "the bottom-up processing model assumes that listening is a process of decoding the sounds that one hears in a linear fashion, from the smallest meaningful units (phonemes) to complex texts". This model has been referred to as "listener as 
tape recorder view" (Anderson and Lynch, 1988) since it assumes that listeners take in and store messages sequentially, similarly to the way tape recorders do: one sound, one word, one phrase and one utterance at a time.

The top-down interpretation model, on the other hand, claims that listeners reconstruct the original meaning of speakers using incoming sounds as clues (Nunan, 2002). Listeners rely on prior knowledge of the context and of the situation within which the listening takes place to make sense of what they hear. Likewise, Celce-Murcia and Olshtain (2000) point out that topdown listening processes involve the activation of schematic knowledge and contextual knowledge. Schematic knowledge comprises two types of prior knowledge: content schemata, which describe background information on the topic, and formal schemata, which consist of knowledge about different genres, different topics, or different purposes. Contextual knowledge relates to an understanding of the specific listening situation at hand as listeners assess who the participants are, what the setting is and what the topic and purpose are.

Celce-Murcia and Olshtain (2000) advocate that top-down features get filtered through pragmatic knowledge to assist in the processing of oral discourse. They also add that good listeners make use of their understanding of the ongoing discourse or co-text by taking into consideration what has already been said and by predicting what is likely to be said next. The authors (2000) argue that the bottom-up model is generally acknowledged not to be able to operate with any accuracy or efficiency on its own and to require the benefit of and the interaction with top-down information to make discourse comprehensible to listeners. While for native speakers and skilled L2 speakers, bottom-up processing is assumed to be automatic, beginners and less than expert L2 learners are likely to face problems, especially when decoding phonological segments.

In order to compensate for less than automatic bottom-up processing, Celce-Murcia and Olshtain (2000) suggest teaching L2 listening via a strategy-based approachas well as metacognition.This approach teaches learners how to tackle a listening task when not everything is comprehensible and thus requiring the use of special mental processes or learning strategies (Mendelsohn, 1995). Its main aim is to teach students how to listen. Mendelsohn (1995) indicates that a good listening course should have two main aims. Firstly, to help learners develop strategies to recognise and use the signals which are provided in the spoken target language. Secondly, to teach students how to use these signals to predict, guess and infer. Therefore, learners need practice in the following strategies: determining setting, interpersonal relations, mood, topic, the essence of the meaning of an utterance; forming hypotheses, predictions and inferences; and determining the main idea of a passage.

Mendelsohn's framework $(1995,1998)$ for the teaching of strategy-based listening to second language learners can be summarised as follows (In: Celce-Murcia and Olshtain, 2000:103): 
1. Raise learners' awareness of the power and value of using strategies;

2. Use pre-listening activities to activate learners' background knowledge;

3. Make clear to learners what they are going to listen to and why;

4. Provide guided listening activities designed to offer a lot of practice in using a particular strategy using simplified data initially if needed;

5. Practise the strategy using real data with focus on content and meaning;

6. Use what has been comprehended: take notes on a lecture to prepare a summary, fill in a form to gather data, etc;

7. Allow for self-evaluation so that learners can assess how accurate and complete their listening has been.

In addition, Celce-Murcia and Olshtain (2000) suggest that learners can make use of metacognition in order to enhance their listening skill. Metacognition involves the planning, regulation, monitoring and management of listening and it is closely related to the above listening strategies 1,2,3 and 7. Metacognitive strategies allow learners to have an overview of the listening process by predicting, monitoring errors or breakdowns in understanding and evaluating the success of comprehension.

Furthermore, the characterisation of listening purposes also depends on the nature of the listening event (Richards, 1985). Students may be exposed to listening as a component of social interaction (e.g. conversational listening), listening for information, academic listening (e.g. lectures), listening for pleasure (e.g. radio, movies, television), or for some other reason. Based on the analyses of listening processes and on the features of spoken discourse, Richards (1985:198-199) proposes taxonomies of listening micro-skills for different listening events.

\section{Empirical Project}

Corsetti (2009) investigated the effectiveness oflistening comprehension activities to promote pragmatic development via a strategy-based approach to listening. The activities were implemented in a classroom project developed in the first semester of 2009, which was part of a broader empirical project whose main aim was to corroborate, refute or reject the following assumptions:

1. In order to achieve listening proficiency, learners need practice in making inferences as semantic and pragmatic inferences are embedded in verbal communication;

2. Semantic and pragmatic aspects affecting the meaning of utterances can be highlighted via comprehension activities focusing on specific listening sub-skills;

3. Following a strategy-based approach, listening activities can directly and indirectly enhance pragmatic comprehension and pragmatic production. 
The classroom project included the participation of eight Brazilian learners of English as a second language, who were taking a preparatory course for the IELTS $^{3}$ examination at a language institute in the south of Brazil in the first semester of 2009. Their age range varied from mid-twenties to late-forties. Students attended 1 hour and 15 minute- lessons twice a week amounting to an overall exposure of 48 hours in the semester. Students were highly motivated and committed as their main course aim was to achieve satisfactory grades in the IELTS examination in order to be eligible to work or study in English speaking countries.Broadly speaking, learners' overall linguistic competence ranged from intermediate to advanced levels due to the nature IELTS, which is a multi-level examination.

The classroom project was developed considering learners' needs and how events unfolded during the semester. It did not follow any rigorous scientific methodology but rather attempted to improve learners' overall listening proficiency. Despite its experimental nature, at the end of the semester learners' listening band scores had risen at least one and a half bands. The assessment of students' linguistic and pragmatic abilities relied on the following instruments: IELTS mock tests(Jakeman\&Mcdowell, 1999:127-159, McCarter \& Ash, 2003:8124), IELTS band scores (IELTS handbook 2007: 4) and pragmatic competence quizzes(Corsetti, 2009:173-184).

The empirical project consisted of the following stages:

1. Assessment of learners' linguistic competence via IELTS mock test 1;

2. Analysis of learners' listening needs vis-à- vis listening scores;

3. Selection of supplementary listening materials at different levels of listening proficiency for individual learners;

4. Production of a pragmatic competence quiz (phase one);

5. Assessment of learners' pragmatic competence via the pragmatic quiz;

6. Analysis of learners' pragmatic needs vis-à- vispragmatic comprehension;

7. Selection of listening exercises to be used throughout the semester;

8. Monthly re-assessment of learners' linguistic competence via IELTS mock tests 2, 3 and 4;

9. Final assessment of learners' linguistic competence via IELTS mock test 5;

\footnotetext{
3"IELTS"stands for "International English Testing System" and it is aimed at assessing the language ability of candidates over the age of 16 who need to work or study where English is the language of communication. It is jointly managed by Cambridge English Language Assessment, British Council and IELTS Australia. It is recognised by many universities, employers, professional bodies, immigration authorities and government agencies, in countries like Australia, New Zealand, Canada, the UK and the USA. It tests candidates' ability in the four language skills: listening, reading, writing and speaking. Candidates are awarded a score on a band scale from (1) to (9) for each test component. The scores are averaged and rounded to produce an overall Band Score reported as a whole band or a half band. An IELTS average Band Score of (6.5) is usually required by most universities and colleges in the above countries. However, some institutions may request higher scores(IELTS handbook 2007).
} 
10. Production of pragmatic competence quiz (phase two);

11. Re-assessment of learners' pragmatic competence via the pragmatic quiz (phase two);

12. Analyses of students' results and of the effectiveness of listening activities to promote pragmatic development.

The results of the empirical project led to the following conclusions:

1. Subjects' initial assessment of language abilities via mock test 1 indicated that listening was the language skill which posed the most difficulty to learners;

2. TheIELTS listening activities ${ }^{4}$ subjects were exposed to providedthemwith pragmatic input;

3. Pragmatic input embedded in the extracts was activated following a strategy-based approach to listening, which encompassed both pre-listening activities and listening activities targeting at specific listening micro-skills;

4. By doing those activities, all subjects raised their overall level of listening proficiency substantially, as suggested by the comparison between mock 1 and mock 5 results ${ }^{5}$;

5. By doing those activities, all subjects improved their pragmatic comprehension in areas such as the interpretation of pragmatic inferences and conversational implicatures, the recognition of the illocutionary force of utterances and reference assignment, as suggested by the comparison between pragmatic competence quizzes results ( phase one and phase two);

All things considered, it was possible to conclude that listening comprehension activities are potentially capable of directly enhancing pragmatic comprehension via a strategybased approach to listening. While pre-listening activities can activate learners' content and formal schemata, listening activities focusing on specific conversational and academic listening micro-skills can draw learners' attention to pragmatic phenomena embedded in verbal communication. However, the results of the empirical project were inconclusive as to the extent to which listening comprehension activities are potentially capable of enhancing pragmatic production.

\section{Conclusion}

In this article, I presented strategy-based listening as an alternative methodological approach to the development of pragmatic comprehension. Pragmatic comprehension comprises the understanding of speech acts and conversational implicatures. Bottom-up comprehension processes involve prior knowledge of the language system in terms of phonology, grammar and vocabulary and encompass the decoding of sounds in a linear fashion. Top-down processes include the activation of schematic knowledge and contextual knowledge.

\footnotetext{
${ }^{4}$ For a full description of the listening activities and how they were implemented, see "Insight into IELTS" (Jakeman\& MacDowell, 1999:8-25) and Corsetti (2009: 126-132)

${ }^{5}$ For detailed results and comparisons, see Corsetti (2009: 143-150)
} 
It was concluded that the bottom-up model does not suffice to make discourse comprehensible to listeners and requires the benefit of and the interaction with top-down information.

A strategy-based approach to listening includes both pre-listening activities, which enable learners to activate their background knowledge on the topic, and listening activities, which give learners the opportunity to practise specific strategies or micro-skills. The empirical project carried out with a group of eight learners preparing for the IELTS examination in 2009 corroborated the following assumptions: in order to achieve listening proficiency, learners need practice in making inferences as semantic and pragmatic inferences are embedded in verbal communication; semantic and pragmatic aspects affecting the meaning of utterances can be highlighted via comprehension activities focusing on specific listening sub-skills; following a strategy-based approach, listening activities can directly enhance pragmatic comprehension.

\section{References}

Anderson, A.; Lynch, T. (1988). Listening. Oxford: Oxford University Press.

Austin, J. (1962). How to Do Things with Words. Oxford University Press.

Brown, G. (1990). Listening to Spoken English. London: Longman.

Celce-Murcia, M.; OlshtainL, E.(2000). Discourse and Context in Language Teaching: a

Guide for Language Teachers. Cambridge University Press.

Corsetti, C.R. (2009) The Enhancement of Pragmatic Competencies via Listening Activities.Master'sthesis. Pontifícia Universidade do Rio Grande do Sul.

Ellis, R.(2002).Grammar Teaching- Practice or Consciousness-raising? In: Richards， J.C.; Renandya, W.A. Methodology in Language Teaching. Cambridge University Press.

Garcia, P. (2004) Pragmatic Comprehension of High and Low Language Learners. Teaching English as a Second or Foreign Language. Electronic Journal, v.8. n.2. Available in: <http://www.tesl-ej.org/ej30/a1abs.html>. Acessed in: 15 dez. 2008.

Grice, E, P. (1975) Logic and Conversation. In Cole, P.; Morgan, J. (eds.). Syntax and Semantics. New York: Academic Press, v.3:41-58.

IELTS Organisation.IELTS Handbook 2007. Available in:<http://www.ielts.org>. Acessed in:15. nov. 2008 
Jakeman, V; MacDowell, C. (1999).Insight into IELTS Student's Book Updated Edition: The Cambridge IELTS Course. Cambridge University Press.

Krashen, S. (1985)The Input Hypothesis: Issues and Implications. Longman.

Leech, G. N.( 1977).Language and Tact.Treer: University of Treer.

Levinson, S.C. (1983) Pragmatics. Cambridge University Press.

McCarter, S.; Ash, J. (2003).IELTS Testbuilder. Macmillan.

Mendelsohn, D. (1995) Applying Listening Strategies in the Second/Foreign Language Listening Comprehension Lesson. In: Mendelsohn, D. \& Rubin, J. (Eds.) A Guide for the Teaching of Second Language Listening. San Diego, CA: Dominie Press.

Mendelsohn, D. (1998). Teaching Listening. Annual Review of Applied Linguistics.

Nunan, D. (2002). Listening in Language Learning. In: Richards, J.C.; Renandya, W.A. Methodology in Language Teaching. Cambridge University Press.

Richards, J.C. (1985). Listening Comprehension: Approach, Design, and Procedure. In: . The Context of Language Teaching. Cambridge University Press.

Richards, J.; Platt, J.; Weber, H. (1990) Longman Dictionary of Applied Linguistics. Longman

Rost, M. (1990). Listening in Language Learning. New York: Longman.

Searle, J. (1969) Speech Acts: An Essay in the Philosophy of Language. Cambridge University Press.

Searle, J. (1979) Expression of Meaning: Studies in the Theory of Speech Acts. Cambridge University Press.

Swain, M. (1985) Communicative Competence: Some Roles of Comprehensible Input and Comprehensible Output in Its Development. IN: Gass, S.; Madden, C. (Eds.). Input in Second Language Acquisition. New York: Newbury House. 
Thomas, J. (1995) Meaning in Interaction: An Introduction to Pragmatics. London: Longman.

Willis, J. (1996). A Flexible Framework for Task-Based Learning. In: Willis, J; Willis, S, D.

(Eds.) Challenge and Change in Language Teaching. Oxford: Heinemann. 